\title{
THE MAIN SULPHIDE ORE BELT OF FINLAND BETWEEN LAKE LADOGA AND THE BOTHNIAN BAY
}

\author{
AARNO KAHMA
}

\begin{abstract}
KAHMA, AARNO 1978: The main sulphide ore belt of Finland between Lake Ladoga and the Bothnian Bay. Bull. Geol. Soc. Finland 50: $39-43$.

The formation of the Main Sulphide Ore Belt of Finland (containing $80-90 \%$ of its known sulphide ore resources) can be divided into four main stages: the (1) formation of the Outokumpu- $(\mathrm{Cu}, \mathrm{Co}, \mathrm{Zn})$ and Vihanti-type $(\mathrm{Zn}, \mathrm{Pb}, \mathrm{Cu})$ stratabound mineralizations close to the Archean continental shelf at the evolutionary stage of the Svecofenno-Karelidic orogeny; the (2) partial remobilization, redeposition and recrystallization of the Outokumpu- and Vihanti-type of ores during the revolutionary stage of the Svecofenno-Karelidic orogeny about 1800-1900 Ma ago; the (3) formation of the Kotalahti $\mathrm{Ni}, \mathrm{Cu}$ Ore Zone together with the basic and ultrabasic intrusions in connection with deep movements about $1900 \mathrm{Ma}$ ago; the (4) stepwise sinking (in both space and time) of the Main Sulphide Ore Belt to form steps or grabens, in which the ores were preserved from the erosion during the Proterozoic and Phanerozoic eons. These block movements took place after the Svecofenno-Karelidic orogeny, they are believed to have been caused by the isostatic forces resulting from the denudation of the ancient Svecofenno-Karelidic mountain ranges, situated mainly on the SW side of the Archaean continental shelf. Five points are presented to support the final hypothesis.
\end{abstract}

Aarno Kahma, Mäntyviita 9 C, SF-02100 Espoo 10, Finland.

The main Sulphide Ore Belt of Finland is situated between Lake Ladoga and the Bothnian Bay (Figs. 1 and 2) close to the Archaean continental shelf. It contains about $80-90 \%$ of the known sulphide ore resources of Finland and is divided (Kahma 1973) into three main metallogenic units, viz., the Kotalahti Ni, Cu Ore Zone, the Vihanti $\mathrm{Zn}, \mathrm{Pb}, \mathrm{Cu}$ Ore Zone and the Outokumpu $\mathrm{Cu}, \mathrm{Co}, \mathrm{Zn}$ Ore District, in addition to which there is the separate Hammaslahti $\mathrm{Cu}$ ore deposit in the SE part of the Belt. The formation of these ore deposits and their preservation from erosion during the Proterozoic and Phanerozoic eons are considered to have occurred in four stages:

(1) The formation of the Outokumpu- and Vihanti-type stratabound mineralizations close to the Archaean continental shelf at the evolutionary stage of the Svecofenno-Karelidic orogeny. 


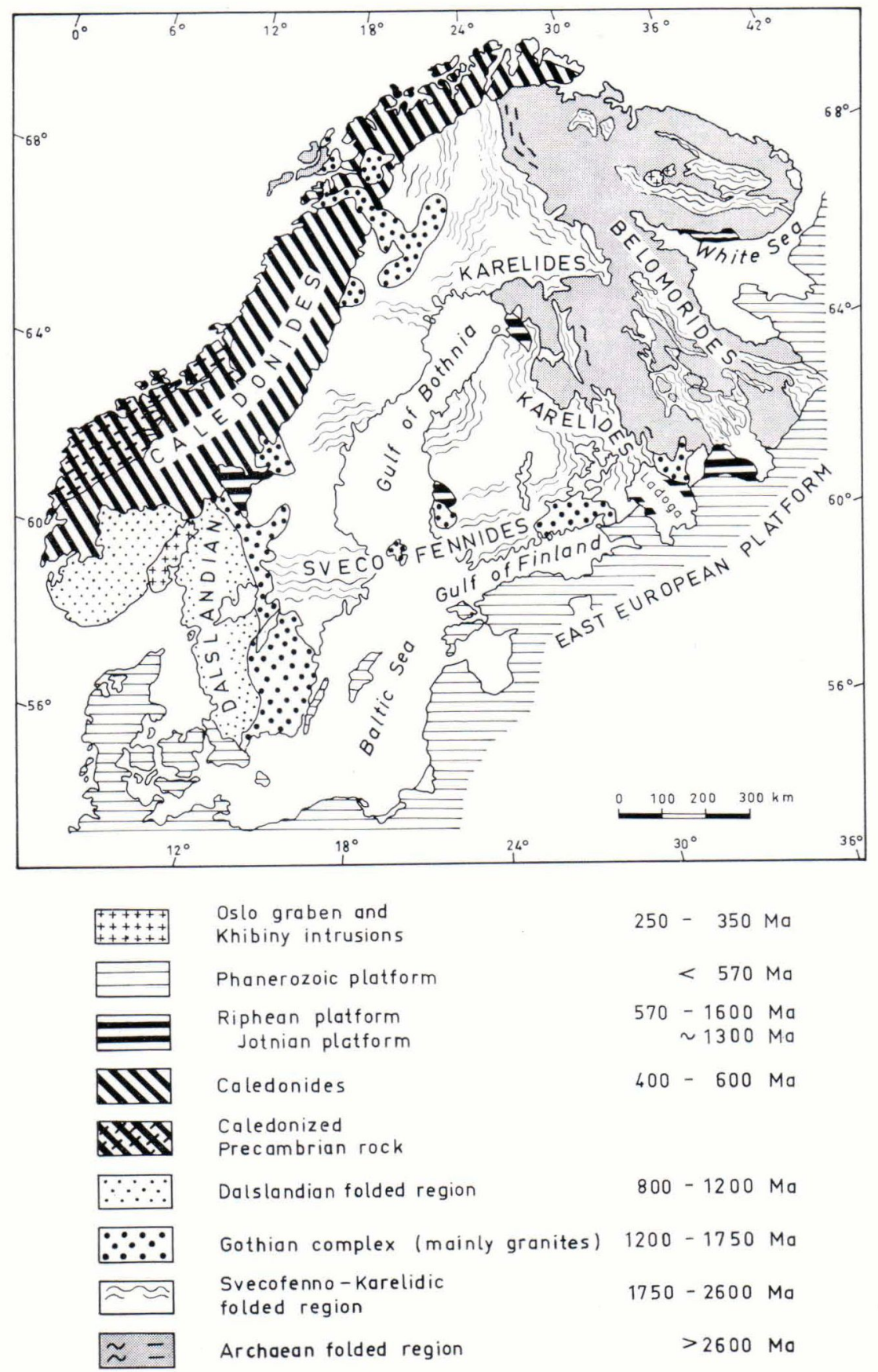

Fig. 1. The main Geologic Units of Fennoscandia. 

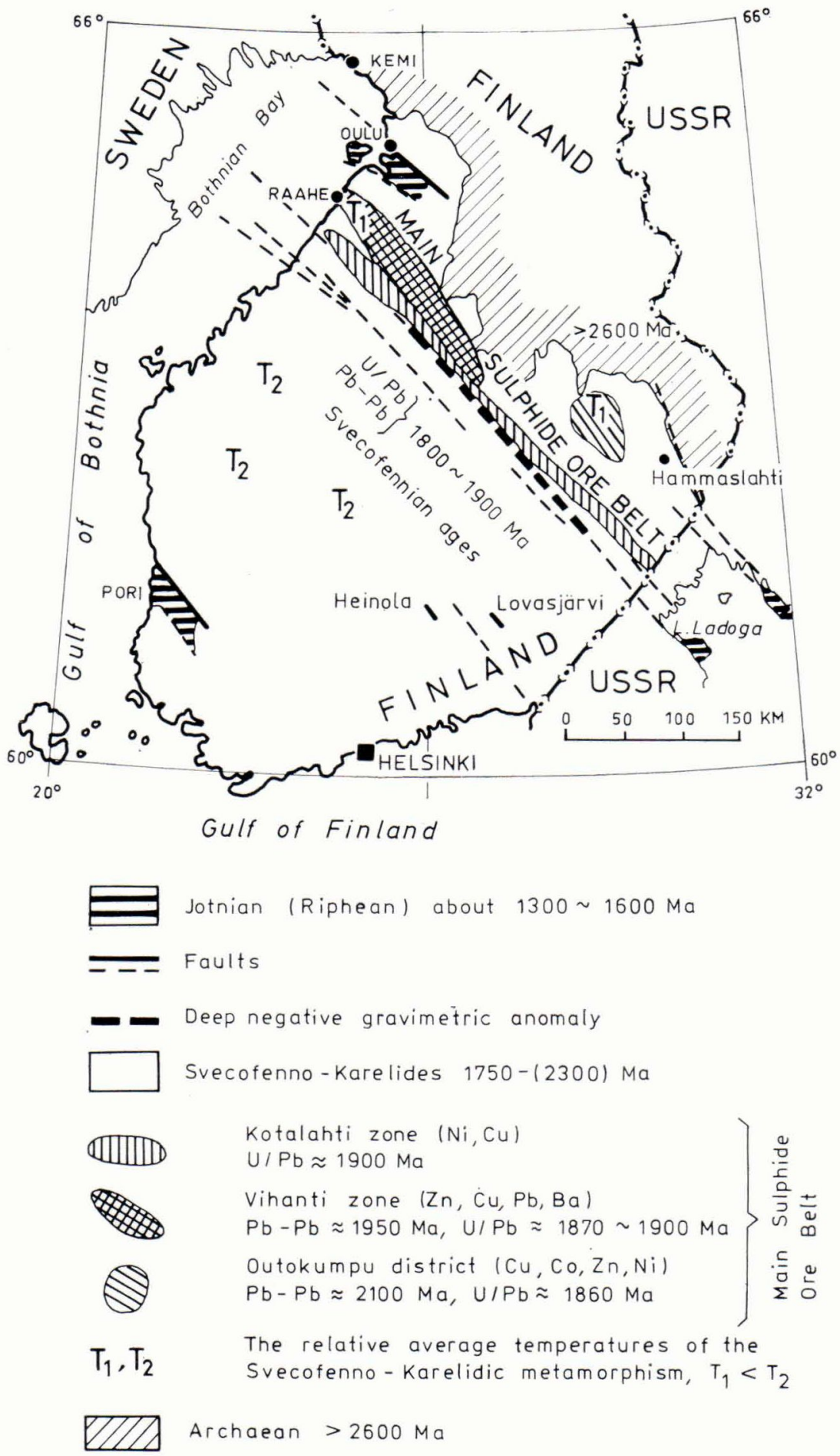

Fig. 2. The main Sulphide Ore Belt and its surroundings. 
(2) The partial remobilization, redeposition and recrystallization of the Outokumpuand Vihanti-type of ores during the revolutionary stage of the SvecofennoKarelidic orogeny about $1800-1900 \mathrm{Ma}$ ago.

(3) The formation of the Kotalahti Ore Zone together with the basic and ultrabasic intrusions in connection with deep movements about $1900 \mathrm{Ma}$ ago.

(4) The stepwise sinking (in both space and time) of the Main Sulphide Ore Belt to form steps or grabens, in which the ores were preserved from the erosion during the Proterozoic and Phanerozoic eons. These block movements took place after the Svecofenno-Karelidic orogeny, they are believed to been caused by the isostatic forces resulting from the denudation of the ancient Svecofenno-Karelidic mountain ranges, situated mainly on the SW side of the Archaean continental shelf (Figs. 1 and 2).

The sulphide ore types and their genesis belonging into points (1)-(3) have been dealt with in many papers. They have been marked on a map, and a genetic model has been presented by the author (Kahma 1973). Since then they have also been discussed by, e.g., Helovuori (1974), Gaál et al. (1975), Piirainen (1975), Peltola (1977), Gaál (1977), Hyvärinen et al. (1977), Isokangas (1977), Mikkola et al. (1977); see also the plate-tectonic model by Hietanen (1975).

The hypothesis propounded in point (4) is, as far as I know, new and can be supported by the following facts and points of view:

1. Riphean formations are found on the east and west shores of Lake Ladoga. Jotnian formations - a part of the Riphean are found in the Oulu and Pori grabens. Seismic measurements and diamond drillings (Veltheim 1969) show that the thickness of the Jotnian sediments varies — probably stepwise - from $30 \mathrm{~m}$ up to $1 \mathrm{~km}$.

2. SE-NW-striking diabase dikes are known to exist in the Lovasjärvi and Heinola areas (Laitakari 1969), (Fig. 2), the radiometric ages of which are $1670 \mathrm{Ma}$ and $1550 \mathrm{Ma}$, respectively. Diabases and basic effusives have also been found in the area of Lake Ladoga. These facts show that some of the SE-NW-striking faults and fractures that appeared after the Svecofenno-Karelidic orogeny have extended into the mantle.

3. Between Lake Ladoga and the Bothnian Bay there is a deep negative gravimetric anomaly $\left(50-250 \mu \mathrm{m} / \mathrm{s}^{2}\right)$ in connection with a fault zone (Fig. 1). On the basis of the bathymetric map (Tulkki 1977), these faults seem to have extensions even on the bottom of the Bothnian Bay.

4. On the southwest side of the deep negative gravimetric anomaly and its extensions in Finnish territory, no places are known where the basement of the SvecofennoKarelidic supracrustal rocks of SW Finland can be seen. The surroundings of these supracrustal rocks, however, are acidic, as on the side of the old eastern Archaean basement $(>2600 \mathrm{Ma})$. These facts, together with the dominance of migmatites $(20-30 \%$ migmatites $+10-$ $20 \%$ crystalline schists of volcanic or sedimentary origin, (Simonen 1962, Kahma 1973) on the SW side compared with the dominance of the crystalline schists on the NE side (over $50 \%$ schists $+10 \%$ migmatites) show that the old basement of SW Finland is strongly ultrametamorphosed. The metamorphic rocks of SW Finland thus represent a higher average metamorphic temperature and probably also a deeper section of the then existing earth's crust than the Main Sulphide Ore Belt. 
5. The radiometric measurements of the samples from the southwest side of the Main Sulphide Ore Belt give consistent so-called Svecofennian ages independent of the radiometric methods used. The lead model ages (Fig. 1) of the sulphides of the Vihanti Ore Zone and the Outokumpu Ore District are somewhat older than these "Svecofennian» ages as well as the ages of their surrounding intrusives. These discordant ages together with the partial remobilization of the Outokumpu- and Vihanti-type sulphide ores as well as the Archaean basement (the formation of mantled domes, Eskola 1949) point to more moderate temperatures during the Svecofenno-Karelidic metamorphism. It does not seem to represent as deep a section of then existing earth crust as in SW Finland, where the daughter nuclides of the radioactive elements have completely separated from their original source minerals (Neuvonen 1961).

Acknowledgements - I am indepted to Mrs. Rauha Tapanainen for the drawings, to Dr. Ilmari Haapala, Drs. Olavi Kouvo and Matti Vaasjoki for suggestions and to Mr. Paul Sjöblom, M. A., for correcting the English.

\section{References}

Eskola, P. (1949) The problem of mantled domes. Q. J. Geol. Soc. Lond. 104: 461-476.

Gaàl, G. \& Koistinen, T. \& Mattila, E. (1975) Tectonics and stratigraphy of the vicinity of Outokumpu, North Karelia, Finland. Including a structural analysis of the Outokumpu ore deposit. Geol. Surv. Finland, Bull. 271. 67 p.

Gaàl, G. (1977) Structural features of Precambrian, stratabound sulphide-ore deposits in Finland. Geol. För. Förh. 99: 118-126.

Helovuori, O. (1964) Outokumpu Oy, Pyhäsalmen kaivos: Malmiesiintymän geologia. English summary. Vuoriteollisuus 22 (1): 22-24.

Hietanen, A. (1975) Generation of potassium-poor magmas in the Northern Sierra Nevada and the Svecofennian of Finland. Jour. Research U. S. Geol. Survey (6): 631-645.

Hyvärinen, L. \& Kinnunen, $K$. \& Mäkelä, $M$. (1977) The geochemistry, fluid inclusions, sulfur isotopes and origin of the Hammaslahti copper ore deposit, Finland. Geol. Surv. Finland, Bull. 293. 23 p.

Isokangas, P. (1977) The mineral deposits of Finland. In »The mineral deposits of Europe. Part I. Northern Europe». The Institution of Mining and Metallurgy. London (in print).

Kahma, A. (1973) The main metallogenic features of Finland. Geol. Surv. Finland, Bull. 265. 29 p.
Laitakari, I. (1969) On the set of olivine diabase dikes in Häme, Finland. Geol. Surv. Finland, Bull. 241. 65 p.

Mikkola, A. \& Vuorela, P. (1977) Deep-seated fractures and metallogeny of Finland. Proceeding of a Finnish-Soviet symposium held in Finland 20-24 Sept. 1976. Helsinki, 1977.

Neuvanen, K. (1961) The apparent age pattern of the crust. C. R. Soc. Géol. Finlande 33: 445454; also Bull. Comm. Géol. Finlande 196.

Peltola, E. (1978) Origin of Precambrian copper - zink sulphides of the Outokumpu district, Finland. Ec. Geol. 73 (4): 461-477.

Piirainen, T. (1975) The Svecokarelian orogenic cycle and related metal genesis in Finland. Bull. Geol. Soc. Finl. 47 (1-2): 139-153.

Simonen, A. (1962) Alter und allgemeine Charakteristik des finnishen Grundgebirges. Geol. Rundschau 52 (1): 256-260.

Tulkki, P. (1977) The bottom of the Bothnian Bay geomorphology and sediments. Merentutkimuslait. julk./Havsforsckningsinst. Skr. 241: 5-89.

Veltheim, V. (1969) On the pre-Quarternary geology of the Bothnian Bay area in the Baltic Sea. Bull. Comm. Géol. Finlande 239. 56 p.

Manuscript received, March 2, 1978. 